\title{
Educational Content Generation for Business and Administration FL Courses with the NBU PLT Platform
}

\author{
Associate Prof. Dr. Maria STAMBOLIEVA \\ Laboratory for Language Technologies, New Bulgarian University \\ mstambolieva@nbu.bg
}

\begin{abstract}
The paper presents a project of the Laboratory for Language Technologies of New Bulgarian University (NBU) - "E-Platform for Language Teaching (PLT) ${ }^{1}$ " - the development of corpus-based teaching content for Business English courses. The following methodological issues are briefly discussed to present the background for the development of the platform: 1. problems of e-learning; 2. problems of communicative foreign language teaching; 3. problems of teaching foreign languages for specific purposes; 4. E-learning at NBU. The structure and functionalities of the platform are then outlined, with a focus on corpus development and test generation in teaching foreign languages for specific purposes (TFLSP).
\end{abstract}

\section{E-learning}

E-learning is an important part of modern foreign language acquisition. The Internet abounds in freely accessible language tests, graded presentations of thematic vocabulary and grammar. It also offers freely accessible authentic texts, audio and visual information - which can be used for the purpose of language learning. Most often used as a supplement to traditional classroom tuition, elearning can be an invaluable means of increasing

\footnotetext{
${ }^{1}$ Project funded by the Central Fund for the Strategic Development of NBU for the period 2016-2017.
}

the overall effectiveness of the process of teachingespecially if sufficiently well planned and conceived as an integral part of this process.

The integration of digital instruction with the traditional educational context - known as "blended learning", has been gaining ground since the early years of the new millennium. Bonk and Graham2 define it as the combination of "face-toface instruction with computer mediated instruction". The technological equipment and know-how of teachers and students now being more or less taken for granted, blended learning takes advantage of the versatility of the Internet as a medium of communication. While providing opportunities for personalisation of educational content and individualisation in timing and pace, effective blended learning requires no less careful planning and preparation than traditional brick-and-mortar classes; and the simple addition of available online videos or tests to existing educational content might lend a course flavor but will not necessarily increase its effectiveness.

The need to plan and organise teaching material has resulted in the development of educational platforms. Platforms with ready-for-use content are offered by many publishing houses specialising in foreign language teaching aids and are very popular in schools; most universities however make use of their own platforms, where lecturers develop their own courses. The PLT educational content can be integrated in both.

2 Bonk, C.J. \& Graham, C.R. (2006). The handbook of blended learning environments: Global perspectives, local designs. San Francisco: Jossey-Bass/Pfeiffer. p. 5. 


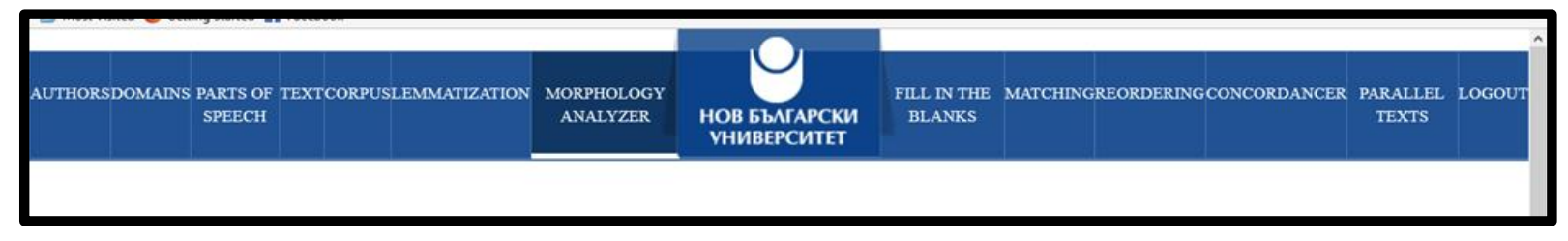

Figure 1. Structure of the platform: modules

\section{E-learning at NBU}

New Bulgarian University is unique not only in Bulgaria, but also in the area of Central and Eastern Europe in that $1 /$ it offers its students over 120 hours per semester of compulsory foreign language teaching and $2 /$ it makes extensive (again, compulsory) use of the Moodle educational platform.

While Moodle is compulsory, not all of its functionalities are made use of by all lecturers. Some simply post additional reading, homework or short messages to the group, others use the forum for group discussions. The necessity to make fuller use of the platform in foreign language classes arose from a recent survey showing a drop in student attendance and performance. Accordingly, the year 2016 marked the development of: 1/ a unified "backbone" educational content for blended or distance learning for each CEFRL; 2/ the development of the PLT as an additional support to Moodlebased general language courses and a main support to courses in foreign languages for specific purposes. One of the major aims of the PLT project is to provide course support for lecturers and students in the over $50 \mathrm{BA}$ programs of the university in the form of domain-specific online texts, text-based exercises and tests for both regular and distancelearning programmes and courses.

\section{Teaching FL for specific purposes}

Following several successful pilot tests during the academic year 2016/2017, from October 2017 weekly PLT-based tuition will be available for students taking courses in the "Applied Foreign Languages for Administration and Management" BA programme. In designing the course, we have followed McDonough and J.S. Shaw (1993: 243ff.) who define the ideal system for teaching foreign languages for specific purposes as one that allows individualisation of the learning process. In the usual conditions (classroom, group) such individualisation can hardly be achieved: while the needs of the trainees are symmetrical, the groups are often heterogeneous - which can significantly reduce the motivation of the learners. As P. Hemingway (1987: 18) points out, "a mixed level class can be demotivating for students if they are not encouraged to work to their own limits, and enabled to fully participate in the lesson. The student whose English is more advanced than the rest may feel cut off from the group if he/she is constantly given work to do alone, while the others catch up".

Foreign language teaching for specific purposes does not necessarily follow training in the generalpurpose language; it can successfully be conducted alongside with it, or even on its own (Cf. DudleyEvans \& St. John, 1998: 4-5). It should provide the trainees with the freedom to choose the learning content and provide them with appropriate teaching material and sufficient training exercises. The learning process has a greater degree of autonomy and greater freedom of choice as to when, what, and how to study. The role of the lecturer is reduced to that of a professional consultant who designs the course, selects (possibly adapts) the teaching materials, designs and arranges the exercises to them, checks and evaluates the work of the students. (Cf. Carver 1989: 134).

\section{Structure and functionalities of the Platform}

The PLT system comprises:

- a repository of domain-specific texts, further classified in accordance with the Common European Framework of Reference for Languages (CEFRL);

- a module for corpus creation;

- a linguistic data base integrating the results of lemmatisation, POS-tagging, morphemic and syntactic analysis, term identification and definition, multiple-word term identification;

- a set of test-generation modules generating drills based on: a. text degradation, b. reordering, c. multiple matching;

- a concordance and a parallel texts aligner. 


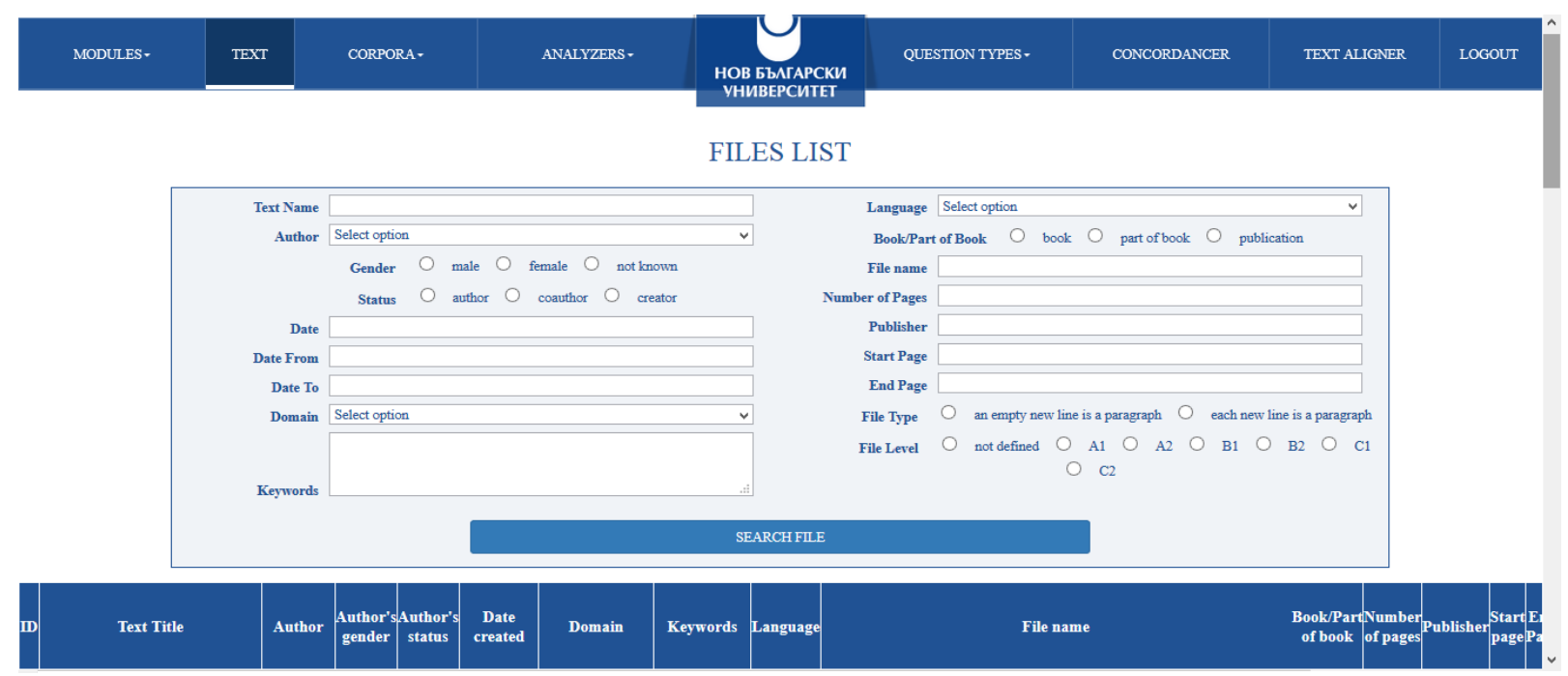

Figure 2. The PLT text classifier
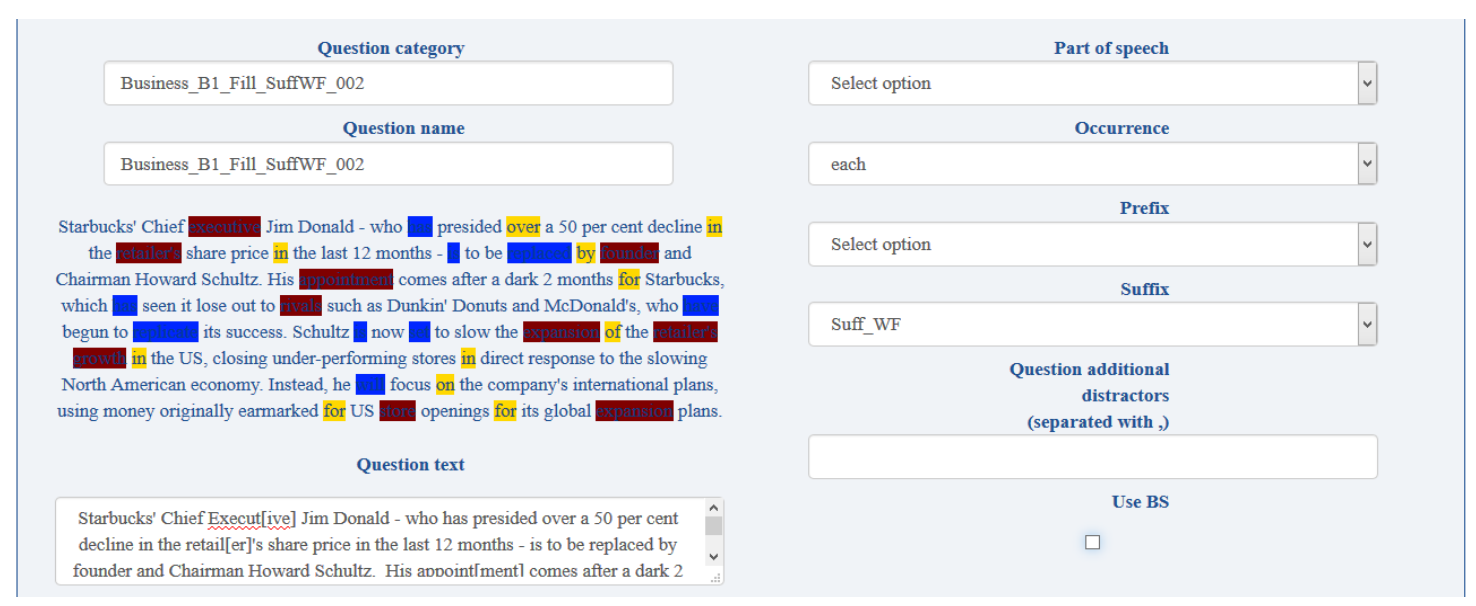

Figure 3. Generation of a Fill in the Blanks exercise in the PLT

\section{Creating a Domain- and CEFRL- based corpus}

The corpus for the domain of Administration and Business is, for now, subdivided into four sub-corpora - for the CEFRL levels A1, A2, B1 and B2 (to be extended shortly to $\mathrm{C} 1$ and $\mathrm{C} 2$ ). Most texts have been selected from freely accessible sites for business, business news and business writing. In assessing difficulty levels, Laurence Anthony's AntWordProfiler ${ }^{3}$ is used alongside with personal expertise.

The corpora can be united to form general domain-based or other text profile-based corpora; they can also be split. New corpora can be created by corpus-merging operations or by document selection.

\footnotetext{
${ }^{3}$ http://www.laurenceanthony.net/software/antwordprofiler/ releases/AntWordProfiler141/help.pdf
}

\section{Task Generation and the Language Task Bank}

The platform allows the creation of a variety of language drills of the following main types:

- Text degradation exercises based on lemmtisation (open the brackets using an appropriate word form), POS tagging (e.g. fill in the blanks with an appropriate noun / verb / adjective article / preposition, etc.), morphemic analysis (e.g. select/type in an appropriate prefix/ suffix / root). The format of the exercises can be Drag-and-drop, Drop-down or Fill in (Open cloze).

- Multiple matching of terms with definitions, synonyms, information from encyclo- 


\begin{tabular}{|c|c|c|c|c|c|c|c|}
\hline$\square$ & 213 Business_B2_Fill_Adj_002 & $\begin{array}{l}\text { A leader in a [formal], [hierarchical] organization, who is appointed to a [managerial] position, has the right to command and } \\
\text { enforce obedience by virtue of the authority of his position. However, he must possess [adequate] [personal] attributes to match his } \\
\text { authority, because authority is only potentially [available] to him. In the absence of [sufficient] [personal] competence, a manager } \\
\text { may be confronted by an [emergent] leader who can challenge his role in the organization and reduce it to that of a figurehead. } \\
\text { However, only authority of position has the backing of [formal] sanctions. It follows that whoever wields [personal] influence and } \\
\text { power can legitimize this only by gaining a [formal] position in the hierarchy, with commensurate authority. }\end{array}$ & $\begin{array}{l}\text { Прнлагателно } \\
\text { Прил/ - } \\
\text { Adjective /Adj./ }\end{array}$ & each & -1 & -1 & $\begin{array}{l}\text { EXPORT, } \\
\text { Edit, } \\
\text { Delete, } \\
\text { Copy }\end{array}$ \\
\hline$\square$ & 216 Business_B2_Fill_Adj_003 & $\begin{array}{l}\text { In prehistoric times, man was preoccupied with his [personal] security, maintenance, protection, and survival. Now man spends a } \\
\text { [major] portion of his [waking] hours working for organizations. His need to identify with a community that provides security, } \\
\text { protection, maintenance, and a feeling of belonging continues [unchanged] from [prehistoric] times. This need is met by the } \\
\text { [informal] organization and its [emergent], or unofficial, leaders. }\end{array}$ & $\begin{array}{l}\text { Прилагателно } \\
\text { Прил/ - } \\
\text { Adjective /Adj./ }\end{array}$ & each & -1 & -1 & $\begin{array}{l}\text { EXPORT, } \\
\text { Edit, } \\
\text { Delete, } \\
\text { Copy }\end{array}$ \\
\hline$\square$ & 81 Business_B2_Fill_Adj_01 & $\begin{array}{l}\text { Bulgaria is a [parliamentary] republic and the [main] power in the country is the [legislative] one. The National Assembly is a one- } \\
\text { chamber parliament which executes the [legislative] power and the right of [parliamentary] control. The mandate of the National } \\
\text { Assembly lasts } 4 \text { years. There are } 240 \text { members of parliament, who are elected directly by the voters according to the [proportional] } \\
\text { representation system. Parliament's sessions are [public] and the laws and decisions it adopts are [obligatory] for all state } \\
\text { authorities, organizations and Bulgarian citizens. The members of parliament represent not only the voters who have elected them } \\
\text { but all the Bulgarian people. }\end{array}$ & $\begin{array}{l}\text { Прилагателно } \\
\text { Прил/- } \\
\text { Adjective /Adj/. }\end{array}$ & each & & & $\begin{array}{l}\text { EXPORT, } \\
\text { Edit, } \\
\text { Delete, } \\
\text { Copy }\end{array}$ \\
\hline$\square$ & 87 Business_B2_Fill_Adj_02 & $\begin{array}{l}\text { The Government (Council of Ministers) is the [main] representative of the [executive] power. It directs the [domestic] and foreign } \\
\text { policy of the country. The government manages the implementation of the state budget, organizes the management tof the state } \\
\text { property and controls the state administration and the [military] forces. After the elections the [political] body elected nominates the } \\
\text { Prime Minister. The President hands him the mandate for forming the government. Then the Council of Ministers that has been } \\
\text { proposed is presented to the parliament and it votes for it. }\end{array}$ & $\begin{array}{l} \\
\text { Прилагателно } \\
\text { Прил/ - } \\
\text { Adjective /Adj./ }\end{array}$ & each & & & $\begin{array}{l}\text { EXPORT, } \\
\text { Edit, } \\
\text { Delete, } \\
\text { Copy }\end{array}$ \\
\hline
\end{tabular}

Figure 4. Exercises generated on the platform

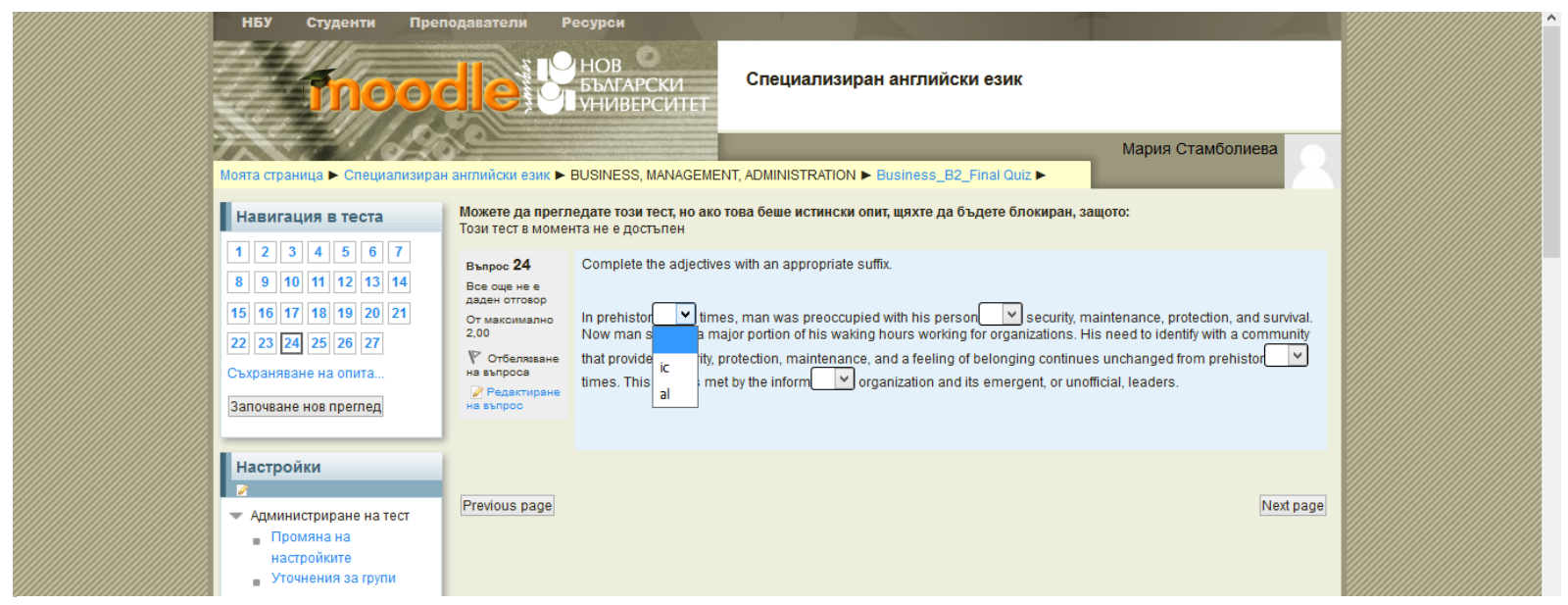

Figure 5. Text-based test

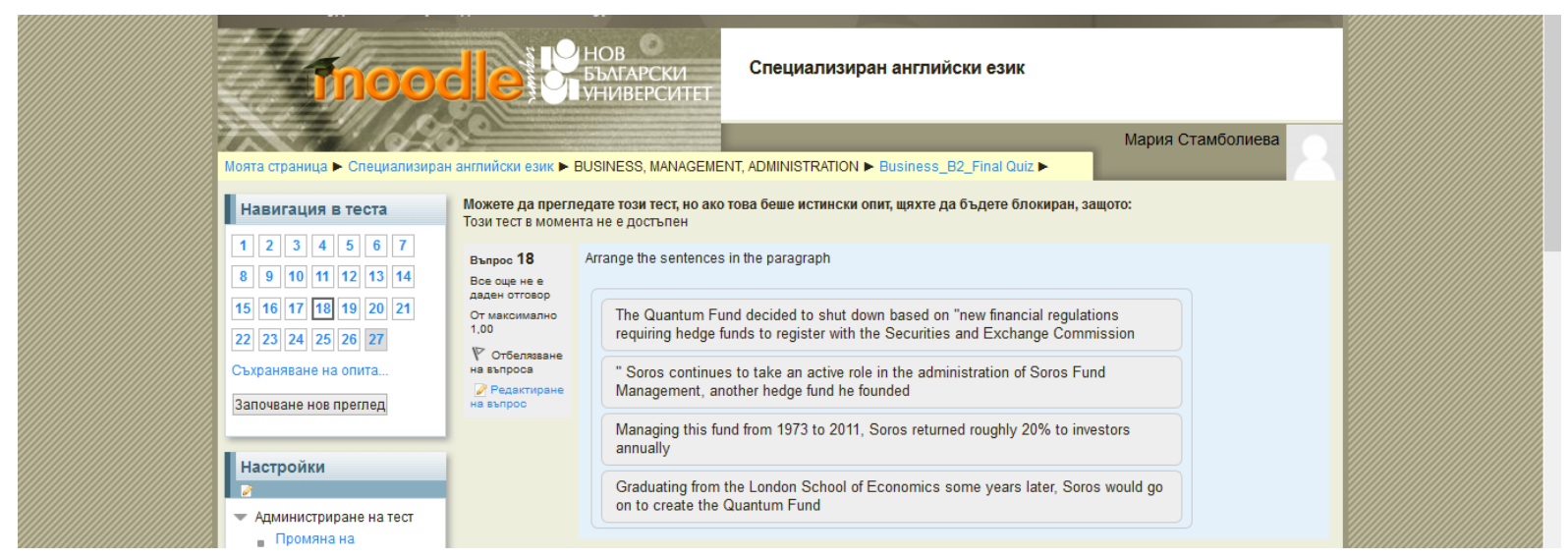

Figure 6. Rearranging task (sentences in paragraph)

pedia, translations - whatever has been entered in the definition box for the term marked at the bottom of the POS analyser. While the methodology of communicative language teaching (CLT) excludes translation, establishing translation equivalence in terminology is an important element of TFLSP - hence the option for translation equivalents of terms in the data base, plus the recent addition of a parallel texts aligner to the system (integration: in development).

- Reordering drills. The platform allows reordering drills for words, phrases and clauses in sentence, sentences in paragraphs and paragraphs in text. Exercises can be edited, if necessary, both in the task-generation module and in the task bank. 


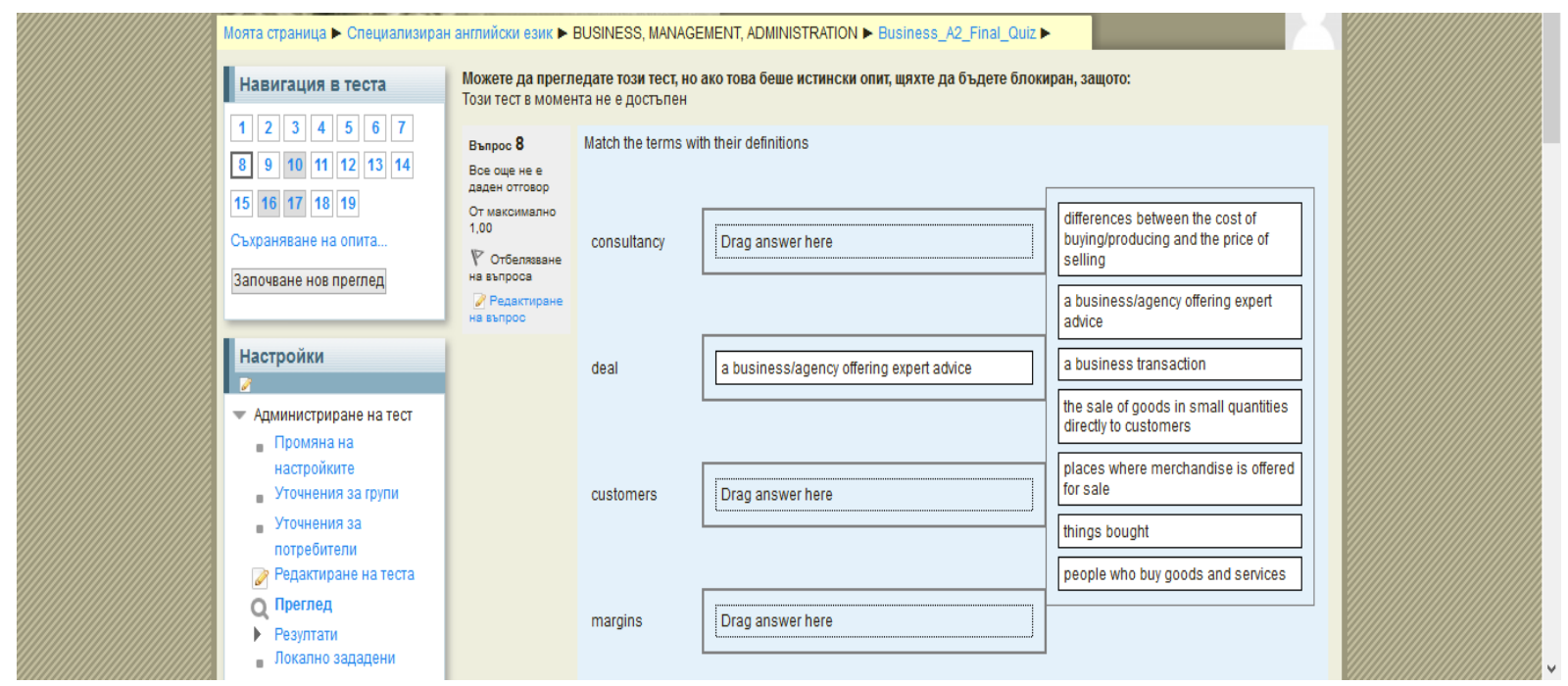

Figure 7. Terminology: Multiple choice 1

\section{Test generation}

The exercises are exported from the platform to a directory and, from there, imported into the educational platform used by the university, school, institute, publishing house, etc. In Moodle, they can be grouped in different ways in tests designed by the tutor. These tests can be either based on one or more texts (and include a variety of lexical or grammatical exercises), or else on task types (e.g. multiple matching exercises for terminology, Fill in the blanks exercises for articles, etc.).

Figure 6 above is a screenshot of a text-based test with 27 different tasks, where task 24 is a multiple choice drop-down exercise on word formation. Task 18 in Figure 6 is a reordering exercise. The task in Figure 7 is a multiple choice exercise on terminology. The order in which the tasks appear in the test can be fixed or variable. Tests can be repeated a limited or unlimited number of times.

\section{Concluding remarks}

The NBU E-platform for language teaching is a flexible, versatile tool which can be used for both education and research. In its application to foreign language teaching for specific purposes, it can successfully support the development of blended or distant courses, offering most of the advantages of e-learning over bricks-and-mortar classes: abundance of drilling material with special attention to structure/form and accuracy, individualisation and personalisation of the learning process, attention to the learner's native language and to accuracy of translation, development of self-reliance and motivation, immediate student and tutor feedback and easy centralized monitoring.

After less than a year of successful testing, the PLT is gradually becoming part and parcel of the general and specialised language teaching at NBU. The creation and constant development of the CEFRL corpus in the domain of business and administration allows the introduction of PLT-based tuition from the academic year 2017/2018.

\section{References}

Anthony, Laurence 2014. http://www.laurenceanthony.net/software/antwordprofiler/releases/AntWordProfiler141/help.pdf

Bonk, C.J. \& Graham, C.R. (2006). The handbook of blended learning environments: Global perspectives, local designs. San Francisco: JosseyBass/Pfeiffer. p. 5.

Carver, D. 1983. Some propositions about ESP. The ESP Journal, 2, pp. 131-137.

Dudley-Evans, T, M. St John, 1998. Developments in ESP: A multi-disciplinary approach. Cambridge: Cambridge University Press.

Hemingway, P., 1986. Teaching a mixed-level class, Practical English Teaching, pp. 18-20.

McDonough, J., C. 1993. Shaw. Materials and Methods in ELT. Cambridge, Mass.: Blackwell. 